\title{
Impact of Heavy Metal lons on the Simultaneous Saccharification and Fermentation of Formosan Alder Biomass to Form Lactic Acid
}

\author{
Chun-Han Ko, ${ }^{\mathrm{a}} \mathrm{Ko}-\mathrm{Yu}$ Liu, ${ }^{\mathrm{a}}$ Bing-Yuan Yang, ${ }^{\mathrm{a}}$ Fang-Chih Chang, ${ }^{\mathrm{b}, *}$ and \\ Po-Heng Lin ${ }^{c}$
}

\begin{abstract}
Formosan alder (Alnus formosana) is a fast-growing, adaptable, pioneer native tree species in Taiwan, and it is particularly suitable for reforestation. In this study, steam-exploded Formosan alder biomass was employed to investigate lactic acid production by simultaneous saccharification and fermentation (SSF) in the presence of different heavy metals. Impacts of added heavy metals on saccharification processing were investigated. In the presence of $1410 \mathrm{mg} \mathrm{Cr}{ }^{6+} / \mathrm{L}$, negative impacts were observed for SSF. The same level of $\mathrm{Cr}^{6+}$ adversely affected fermentation by Lactobacillus casei and L. acidophilus compared to the blank controls. Positive impacts for SSF by $\mathrm{Cd}^{2+}$ were demonstrated with $108 \mathrm{mg} \mathrm{Cd}^{2+} / \mathrm{L}$, and the same conditions favored fermentation by $L$. casei and $L$. acidophilus. No impacts for $S S F$ by $\mathrm{Pb}^{2+}$ up to $6830 \mathrm{mg} \mathrm{Pb}^{2+} / \mathrm{L}$ were found for both Lactobacillus strains. This study demonstrates that SSF for production of lactic acid from Formosan alder biomass was able to tolerate a wide range of heavy metal concentration regimes. Hence, this study provides an alternative use for biomass harvested from phytoremediation sites. Such biomass can be used as sustainable regenerative biomaterial, and thereby it can further enhance the benefits of environmental remediation.
\end{abstract}

Keywords: Alnus formosana; Heavy metals; Lactobacillus; Enzyme hydrolysis; Lactic acid

Contact information: a: School of Forest and Resources Conservation, National Taiwan University, Taipei 10617, Taiwan; b: The Experimental Forest, College of Bio-Resources and Agriculture, National Taiwan University, No. 12, Section 1, Chien-Shan Road, Chu-Shan, Nan-Tou 55750, Taiwan; c: Taiwan Forestry Research Institute, Taipei 100, Taiwan; *Corresponding author:d90541003@ntu.edu.tw

\section{INTRODUCTION}

Some heavy metals are naturally present in soils at trace levels (e.g., $\mathrm{Cd}, \mathrm{Cr}, \mathrm{Cu}$, $\mathrm{Ni}, \mathrm{Pb}$, and $\mathrm{Zn}$ ), but higher levels can be reached due to industrial-related activities. The release of an enormous amount of potentially toxic compounds has resulted from improper management and disposal of heavy metals (Yu et al. 2019). Soil contamination by heavy metals has raised concerns over public health and the ecosystem because of their carcinogenic and mutagenic effects. Phytoremediation is highly regarded as an alternative method for soil and groundwater pollution remediation globally. However, there is a need to explore its application for biomass harvested from polluted sites after remediation.

Formosan alder (Alnus formosana) is a medium-sized deciduous tree endemic to Taiwan, where it grows fast and often forms pure stands in eroded or denuded areas. It is also a shade-intolerant pioneer tree species that grows along river banks and in other open habitats (Wang and Chien 2016). Formosan alder is a nitrogen fixing species, and it is also 
an ideal tree species for afforestation of eroded areas and for soil and water conservation (Wang and Chien 2016).

Lactic acid is a naturally occurring organic acid that can be used in a wide variety of industries, such as the cosmetic, pharmaceutical, chemical, food, and most recently, the medical industries (Komesu et al. 2017). Lactobacillus plantarum (MF042018) exhibits a high degree of resistance to both nickel (500 ppm) and chromium (100 ppm) with multiple antibiotic resistance index above 0.5 , and so it can be applied as a promising biosorbent for the removal of heavy metals from industrial wastewaters (Ameen et al. 2020). About 350,000 tons of lactic acid are produced globally every year. It also serves as a monomer in the synthesizing of polylactic acid, which is an increasingly important biodegradable and biocompatible polymer (Djukić-Vuković et al. 2019; Le Guenic et al. 2019). Various types of biomass, like cassava bagasse, wheat straw, rice straw, and sugarcane bagasse, have been used to produce lactic acid by simultaneous saccharification and fermentation processes (Unrean 2018; Aulitto et al. 2019; Tu et al. 2019; Chen et al. 2020; Rawoof et al. 2020). It has generally been observed that $\mathrm{pH}$, nutrient source, substrate, and temperature significantly affect the lactic acid production (Abdel-Rahman et al. 2011). Pretreatment, hydrolysis, and fermentation are major steps for producing ethanol and lactic acid from lignocellulosic materials (Tu et al. 2019; Ajala et al. 2020; Cubas-Cano et al. 2020; Ko et al. 2020). Among the pretreatment methods, steam explosion is a physicochemical method used for the pretreatment process that is cost effective and requires relatively low energy (Kumar et al. 2020). Steam explosion has been regarded as an effective process to increase accessible surface area to assist further enzyme hydrolysis (Kumar et al. 2020).

Previous studies have shown that the biomass harvested after phytoremediation could be utilized for bioethanol production (Ko et al. 2017; Geiger et al. 2019; Wu et al. 2020). Ko et al. (2017) found that the enzymatic hydrolysis efficiency for Zn-polluted biomass was $90 \%$ of the unpolluted biomass, while it was $77 \%$ for $\mathrm{Cd}$, and approximately the same for $\mathrm{Cr}$. The fermentation efficiency of the heavy metal containing biomass was higher than the control biomass. Geiger et al. (2019) indicated that hydrolysates produced from $\mathrm{Cu}$ exposed biomass achieved a significantly greater ethanol yield and volumetric productivity compared to those of the control biomass. Wu et al. (2020) also showed that the $\mathrm{Cd}$-accumulated biomass showed greatly enhanced enzymatic saccharification and bioethanol production by significantly increasing cellulose accessibility and lignocellulose porosity. Therefore, both the phytoremediation of heavy metal contaminated soil and value-added cellulosic production in biomass have the potential to fulfill the goal of green remediation and to contribute to sustainability.

There are three ways in which heavy metals can influence cellulase activity in biochemical reactions: (1) complexation; (2) combination with active groups; and (3) reaction with the enzyme (Karaca et al. 2010). This study considered lactic acid production from Formosan alder biomass after the growth of the trees had been employed for phytoremediation of heavy metal contaminated soil. The ions of $\mathrm{Cu}, \mathrm{Cd}$, and $\mathrm{Cr}$ were added to simulate the schemes for the utilization of Formosan alder biomass harvested after phytoremediation. Then, steam-exploded Formosan alder biomass was subjected to SSF for lactic acid production in the presence or absence of the metal ions. Lactobacillus casei and $L$. acidophilus were used in the SSF processes. The impact of heavy metal presence on saccharification and SSF processes were assessed. 


\section{EXPERIMENTAL}

\section{Lactobacilli Strains}

The lactobacilli strains Lactobacillus casei (ATCC 334) and Lactobacillus acidophilus (ATCC 4356) were bought from Bioresource Collection and Research Center (BCRC, Hsinchu, Taiwan). Both strains are facultative anaerobic with an optimal growth temperature of $37^{\circ} \mathrm{C}$. Lactobacillus casei and Lactobacillus acidophilus need distinctive periods of time until the glucose production is exhausted. Lactobacillus casei is known to require $72 \mathrm{~h}$, and Lactobacillus acidophilus needs $144 \mathrm{~h}$. Other characteristics of two Lactobacillus species are as reported (Hammes and Hertel 2006).

The seed culture of bacteria was cultivated in de Man, Rogosa, and Sharpe (MRS) medium, which contained $20 \mathrm{~g} / \mathrm{L}$ glucose, $10 \mathrm{~g} / \mathrm{L}$ beef extract, $10 \mathrm{~g} / \mathrm{L}$ proteose peptone, 5 $\mathrm{g} / \mathrm{L}$ yeast extract, $2 \mathrm{~g} / \mathrm{L}$ ammonium citrate, $5 \mathrm{~g} / \mathrm{L}$ sodium acetate, $0.1 \mathrm{~g} / \mathrm{L} \mathrm{MgSO}_{4} \cdot 7 \mathrm{H}_{2} \mathrm{O}$, $0.05 \mathrm{~g} / \mathrm{L} \mathrm{MnSO} 4 \cdot \mathrm{H}_{2} \mathrm{O}, 2 \mathrm{~g} / \mathrm{L} \mathrm{K}_{2} \mathrm{HPO}_{4}$, and $1 \mathrm{~g} / \mathrm{L}$ polysorbate 80 (Tween 80 ). For inoculum preparation, a separate colony was transferred to a $100-\mathrm{mL}$ Schoot bottle containing 100 $\mathrm{mL}$ MRS medium supplemented with $2 \%(\mathrm{v} / \mathrm{v})$ glucose at $37^{\circ} \mathrm{C}$ for $24 \mathrm{~h}$.

\section{Formosa Alders Biomass}

Fifteen-year-old A. formosana was collected from NTU Experimental Forest of central Taiwan. The bark was removed, wood chips were prepared (width $3 \mathrm{~cm}$, length 4 $\mathrm{cm}$, and thickness $0.5 \mathrm{~cm}$ ), and the chips were milled using a RT-08 grinder. The 60- to 40mesh samples were collected to determine the chemical compositions content by the following standard methodology: moisture content as per TAPPI T258 om-06 (2006), solvent extractive of wood and pulp as per TAPPI T204 cm-07 (2007), holocellulose as per TAPPI T249 cm-09 (2009), Klason lignin as per CNS 14907 (2005), pentosans as per TAPPI T223 cm-01 (2001), and ash content as per TAPPI T211 om-02 (2002).

A. formosana wood chips were pretreated by steam explosion using $1.5 \%$ sulfuric acid. Biomass was air-dried for $24 \mathrm{~h}$ and then soaked in $1.5 \%$ sulfuric acid. The sulfuric acid steam explosion was conducted with a dried solid to liquid ratio of $1: 7$ at $180{ }^{\circ} \mathrm{C}$ for 10 min.

\section{Enzyme Assays and Lactic Acid Fermentation}

First, $1.5 \%$ acid steam-exploded Alnus formosana was hydrolyzed with cellulase complex CTec (Novozyme, Bagsværd, Denmark). The enzyme loadings were equivalent to 1, 5, $10 \mathrm{IU}$ endoglucanase (CMCase) $/ \mathrm{mL}$. Enzyme suspension volumes of $0.4,1$, and 2 $\mathrm{mL}$ were used to deliver 1,5 , and $10 \mathrm{IU} / \mathrm{g} \alpha$-cellulose. Hydrolysis was conducted in a total volume of $100 \mathrm{~mL}$ MRS medium, and $2 \mathrm{~g}$ samples in a $100-\mathrm{mL}$ conical flask. The flasks were water bathed at $37^{\circ} \mathrm{C}$, shaken at $100 \mathrm{rpm}$, and the samples were analyzed by highperformance liquid chromatography (HPLC; Jasco RI-930, Tokyo, Japan).

Next, $5 \mathrm{IU} / \mathrm{g} \alpha$-cellulose CTec, $1.5 \%$ (w/w) dried steam exploded Alnus formosana biomass and $2.5 \mathrm{~mL}$ inoculum solution were added to fermentation broth with designated heavy metal concentration. Lactic acid fermentation was conducted at $37^{\circ} \mathrm{C}$.

The heavy metal ions investigated were chromium $\left(\mathrm{Cr}^{6+}\right)$, copper $\left(\mathrm{Cu}^{2+}\right)$, and cadmium $\left(\mathrm{Cd}^{2+}\right)$, which were prepared as aqueous solutions of $\mathrm{K}_{2} \mathrm{Cr}_{2} \mathrm{O}_{7}, \mathrm{CuSO}_{4} \cdot 5 \mathrm{H}_{2} \mathrm{O}$, and $\mathrm{CdSO}_{4}$ for respective concentrations for enzymatic hydrolysis and fermentation. All reagents used were analytical grade or equivalent. 


\section{Analytical Assay}

Lactic acid was chromatographed on a HPLC system equipped with a reflective index detector (Jasco RI-810), column oven (Col Box), and auto-sampler (JASCO AS950). Before injection, the samples were filtered using a $0.22-\mu \mathrm{m}$ membrane filter. Filtered samples $(20 \mu \mathrm{L})$ were injected into the HPLC system. Lactic acid samples were eluted using $0.009 \mathrm{M} \mathrm{H}_{2} \mathrm{SO}_{4}$ and double distilled water as the mobile phase, separately. The 300 $\mathrm{mm} \times 7.8 \mathrm{~mm}$ column (9 $\mu \mathrm{m}$ ReproGel H, Dr. Maisch GmbH, Germany) was used at 70 ${ }^{\circ} \mathrm{C}$ with a flow rate of $0.7 \mathrm{~mL} / \mathrm{min}$. The results are the averages of triplicate testing.

\section{RESULTS AND DISCUSSION}

\section{Impacts of $\mathrm{Cr}^{6+}$}

The presence of $\mathrm{Cr}^{6+}$ was found to have different impacts on the cellulase activities, enzyme hydrolysis of biomass, and glucose fermentation and SSF of both lactobacilli strains, as shown in Fig. 1. The top panel (Fig. 1a) shows that 14.14 and $141.4 \mathrm{mg} / \mathrm{L}$ of $\mathrm{Cr}^{6+}$ positively impacted cellulase activities, with 116.0 and $106.1 \%$ relative cellulase activities demonstrated. However, the presence of increasing $\mathrm{Cr}^{6+}$ showed a decreasing trend, with $92.2 \%$ relative cellulase activities demonstrated at $1414 \mathrm{mg} \mathrm{Cr}^{6+} / \mathrm{L}$. The presence of $\mathrm{Cr}^{6+}$ did not noticeably impact the extent of enzyme hydrolysis of pretreated biomass. Figure 1(a) shows that relative efficiencies of enzyme hydrolysis of biomass were more than $100 \%$ for all three concentrations of $\mathrm{Cr}^{6+}$. The presence of heavy metal ions can provide additional sites for enzyme-substrate binding or block the catalytic sites to deter enzyme hydrolysis. The results show that the promoting effect was more dominant than the inhibiting effect at a lower $\mathrm{Cr}^{6+}$ concentration.

The middle panel of Fig. 1b shows the relative efficiencies of lactic acid conversions from glucose and biomass SSF by L. casei. Trends for the impact of the presence of $\mathrm{Cr}^{6+}$ on relative lactic acid conversions from glucose and biomass SSF by $L$. case $i$ were similar for the range of $\mathrm{Cr}^{6+}$ employed in this study. Below $100 \mathrm{mg} \mathrm{Cr}^{6+} / \mathrm{L}$, the presence $\mathrm{Cr}^{6+}$ of did not adversely impact the relative efficiencies of lactic acid conversions from glucose and biomass SSF by L. casei. At $1414 \mathrm{mg} \mathrm{Cr}^{6+} / \mathrm{L}$, relative lactic acid conversions from glucose and biomass SSF by L. casei dropped below $20 \%$. Relative efficiencies of enzyme activity and the extent of enzyme hydrolysis of pretreated biomass at $1414 \mathrm{mg} \mathrm{Cr}{ }^{6+} / \mathrm{L}$ were still around $100 \%$, as shown in Fig. 1(a). Hence, the above observation suggested that the stress of $\mathrm{Cr}^{6+}$ might adversely impact the physiology of $L$. casei. Consistent drops of relative lactic acid conversions from both glucose and biomass SSF by $L$. casei suggested that the physiological role $L$. casei played was the deciding factor of the aforementioned trend.

The bottom panel of Fig. 1c shows the relative efficiencies of lactic acid conversions from glucose and biomass SSF by L. acidophilus. Trends for the impact of the presence of $\mathrm{Cr}^{6+}$ on relative lactic acid conversions from glucose and biomass SSF by $L$. acidophilus were quite different for the range of $\mathrm{Cr}^{6+}$ emoplyed in this study. Below 707.01 $\mathrm{mg} \mathrm{Cr}{ }^{6+} / \mathrm{L}$, the presence $\mathrm{Cr}^{6+}$ of did not adversely impact the relative efficiencies of lactic acid conversions from glucose by L. acidophilus. At $141.4 \mathrm{mg} \mathrm{Cr}^{6+} / \mathrm{L}$, relative lactic acid conversion from biomass SSF by $L$. acidophilus dropped below $35.8 \%$. Because relative enzyme activities and lactic acid conversions from glucose at this $\mathrm{Cr}^{6+}$ concentration regime remained, the above finding suggested that the $\mathrm{Cr}^{6+}$ might form a complex with byproducts from biomass SSF blocking lactic acid conversion from biomass SSF by L. acidophilus. 
The above finding demonstrates that $L$. case $i$ can be applied to perform SSF lactic acid conversion from pretreated biomass from presence of less than $100 \mathrm{mg} / \mathrm{L} \mathrm{Cr}^{6+}$ from a practical perspective.

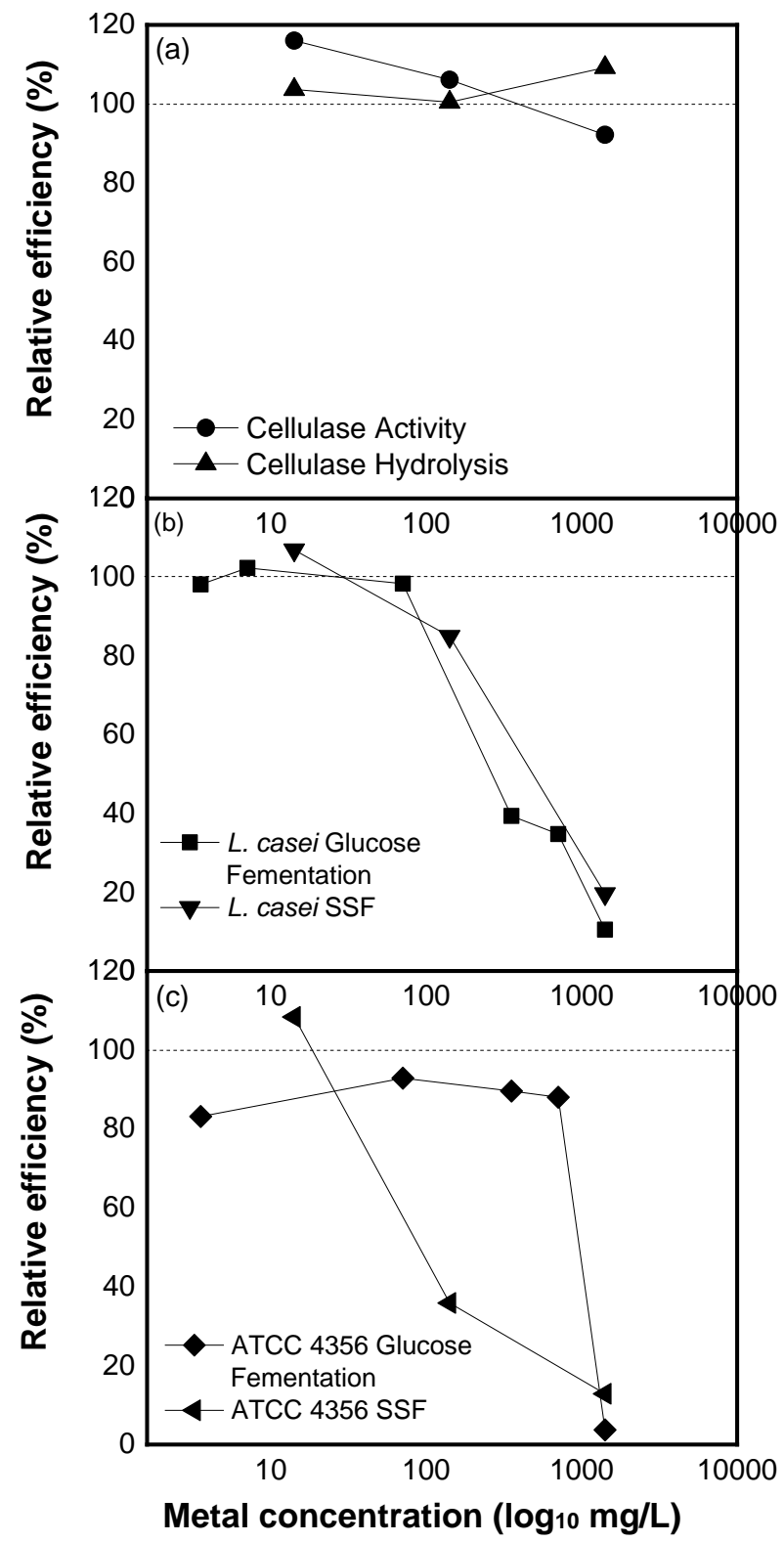

Fig. 1. Impacts of $\mathrm{Cr}^{6+}$ on (a) cellulase activities and enzyme hydrolysis of biomass, (b) glucose fermentation, and (c) SSF of both lactobacilli strains

\section{Impacts of $\mathrm{Cu}^{2+}$}

The presence of $\mathrm{Cu}^{2+}$ exhibited different effects on cellulase activities, enzyme hydrolysis of biomass, glucose fermentation, and SSF of both lactobacilli strains, as shown in Fig. 2. The top panel of Fig. 2a shows that 1.02 and $10.18 \mathrm{mg} / \mathrm{L}$ of $\mathrm{Cu}^{2+}$ positively impacted cellulase activities, with 105.6 and $110.9 \%$ relative cellulase activities demonstrated. However, the presence of increasing $\mathrm{Cu}^{2+}$ inhibited enzyme activity with $92.2 \%$ relative cellulase activities demonstrated at $101.8 \mathrm{mg} \mathrm{Cu}^{2+} / \mathrm{L}$. The presence of $\mathrm{Cu}^{2+}$ 
did not remarkably impact the extent of enzyme hydrolysis of pretreated biomass. Figure 2 a shows that the relative efficiencies of enzyme hydrolysis of biomass were more than $100 \%$ for all three concentrations of $\mathrm{Cu}^{2+}$. Nonetheless, increasing $\mathrm{Cu}^{2+}$ increasingly inhibited enzyme hydrolysis of biomass, with $101.0 \%$ relative cellulase activities demonstrated at $101.8 \mathrm{mg} \mathrm{Cu}^{2+} / \mathrm{L}$. The presence of heavy metal ions can provide additional sites for enzyme-substrate binding or block the catalytic sites to deter enzyme hydrolysis. The results show that the promoting effect was more dominant than the inhibiting effect at a lower $\mathrm{Cu}^{2+}$ concentration. However, for higher $\mathrm{Cu}^{2+}$ concentration, inhibiting effects gradually dominated.

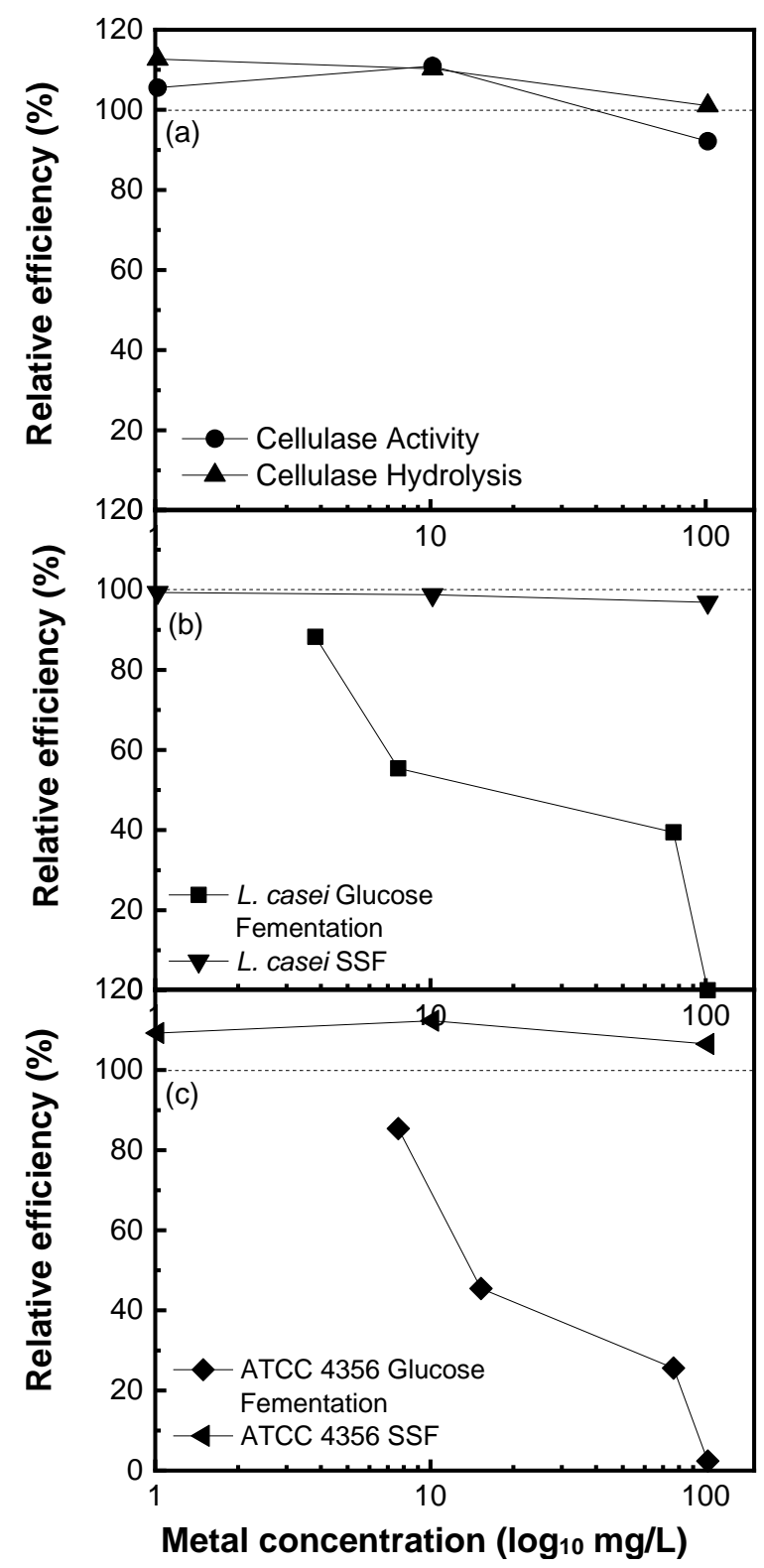

Fig. 2. Impacts of $\mathrm{Cu}^{2+}$ on (a) cellulase activities and enzyme hydrolysis of biomass, (b) glucose fermentation, and (c) SSF of both lactobacilli strains

The middle panel of Fig. $2 b$ shows the relative efficiencies of lactic acid conversions from glucose and biomass SSF by L. casei. Trends for the impact of the 
presence of $\mathrm{Cu}^{2+}$ on relative lactic acid conversions from glucose and biomass SSF by $L$. casei differed greatly for the range of $\mathrm{Cu}^{2+}$ employed in this study. From 1.02 to $101.8 \mathrm{mg}$ $\mathrm{Cu}^{2+} / \mathrm{L}$, the relative efficiencies of lactic acid conversions from biomass SSF by L. casei decreased from 99.3 to $96.9 \%$. The presence of $\mathrm{Cu}^{2+}$ at the range employed in this study did not remarkably impact relative efficiencies of lactic acid conversions from biomass SSF by L. casei, although the relative efficiencies of lactic acid conversions from biomass $\mathrm{SSF}$ was reduced with increasing $\mathrm{Cu}^{2+}$ concentration.

However, the impact of the presence of $\mathrm{Cu}^{2+}$ on relative lactic acid conversions from glucose and L. case $i$ was more remarkable than those from biomass SSF for the range of $\mathrm{Cu}^{2+}$ employed in this study (Fig. 2c). From 3.82 to $76.35 \mathrm{mg} \mathrm{Cu}^{2+} / \mathrm{L}$, the relative efficiencies of lactic acid conversions from biomass SSF by L. casei decreased from 88.2 to $39.4 \%$. The presence of biomass surfaces might provide additional binding sites for $\mathrm{Cu}^{2+}$, preventing $\mathrm{Cu}^{2+}$ from reaching the surface of $L$. casei. Relative efficiencies of lactic acid conversions from biomass SSF by $L$. case $i$ were similar to those of enzyme activities and hydrolysis of biomass. The above findings suggested that the roles played by biomass surfaces might assist in protecting the relative efficiencies of lactic acid conversions from biomass SSF by L. casei from detrimental effects of $\mathrm{Cu}^{2+}$. Performances of lactic acid conversions from biomass SSF by L. acidophilus were superior to those by L. casei in the presence of $\mathrm{Cu}^{2+}$.

The above finding demonstrates that both L. acidophilus and L. casei can be applied to perform SSF lactic acid conversion from pretreated biomass in the presence of less than $100 \mathrm{mg} / \mathrm{L}$ of $\mathrm{Cu}^{2+}$ from a practical perspective.

\section{Impacts of $\mathbf{C d}^{2+}$}

The presence of $\mathrm{Cd}^{2+}$ exhibited different effects on cellulase activities, enzyme hydrolysis of biomass, glucose fermentation, and SSF of both lactobacilli strains, as shown in Fig. 3. The middle panel of Fig. 3a shows that $1.02,10.18$, and $107.8 \mathrm{mg} / \mathrm{L}$ of $\mathrm{Cd}^{2+}$ positively impacted cellulase activities, with $135.3,140.4$, and $124.2 \%$ relative cellulase activities demonstrated, respectively. The presence of $\mathrm{Cd}^{2+}$ did not significantly decrease the extent of enzyme hydrolysis of pretreated biomass. Figure 3a shows that 1.02, 10.18, and $107.8 \mathrm{mg} / \mathrm{L}$ amounts of $\mathrm{Cd}^{2+}$ affected the extents of enzyme hydrolysis of pretreated biomass, with $98.4,117.0$, and $117.7 \%$ relative values. The presence of heavy metal ions can provide additional sites for enzyme-substrate binding or block the catalytic sites to deter enzyme hydrolysis. The results showed that the promoting effect was more dominant than the inhibiting effect at a higher $\mathrm{Cd}^{2+}$ concentration.

The middle panel of Fig. $3 b$ shows the relative efficiencies of lactic acid conversions from glucose and biomass SSF by L. casei. Trends for the impact of the presence of $\mathrm{Cd}^{2+}$ presence on relative lactic acid conversions from glucose and biomass SSF by $L$. casei differed for the range of $\mathrm{Cd}^{2+}$ employed in this study, although the difference was not as large as in the presence of $\mathrm{Cu}^{2+}$. From the range between 1.08 to $107.85 \mathrm{mg} \mathrm{Cu}^{2+} / \mathrm{L}$, the relative efficiencies of lactic acid conversions from biomass SSF by $L$. case $i$ changed from $103.9,107.5$ to $106.6 \%$. The difference between the impacts of the presence of $\mathrm{Cd}^{2+}$ on the relative efficiencies of lactic acid conversions from biomass SSF was smaller than the those from glucose by L. casei. From 8.09 and 21.57 to $53.92 \mathrm{mg}$ $\mathrm{Cu}^{2+} / \mathrm{L}$, the relative efficiencies of lactic acid conversions from glucose by $L$. case $i$ changed from 103.9 and 87.7 to $86.5 \%$, respectively. 


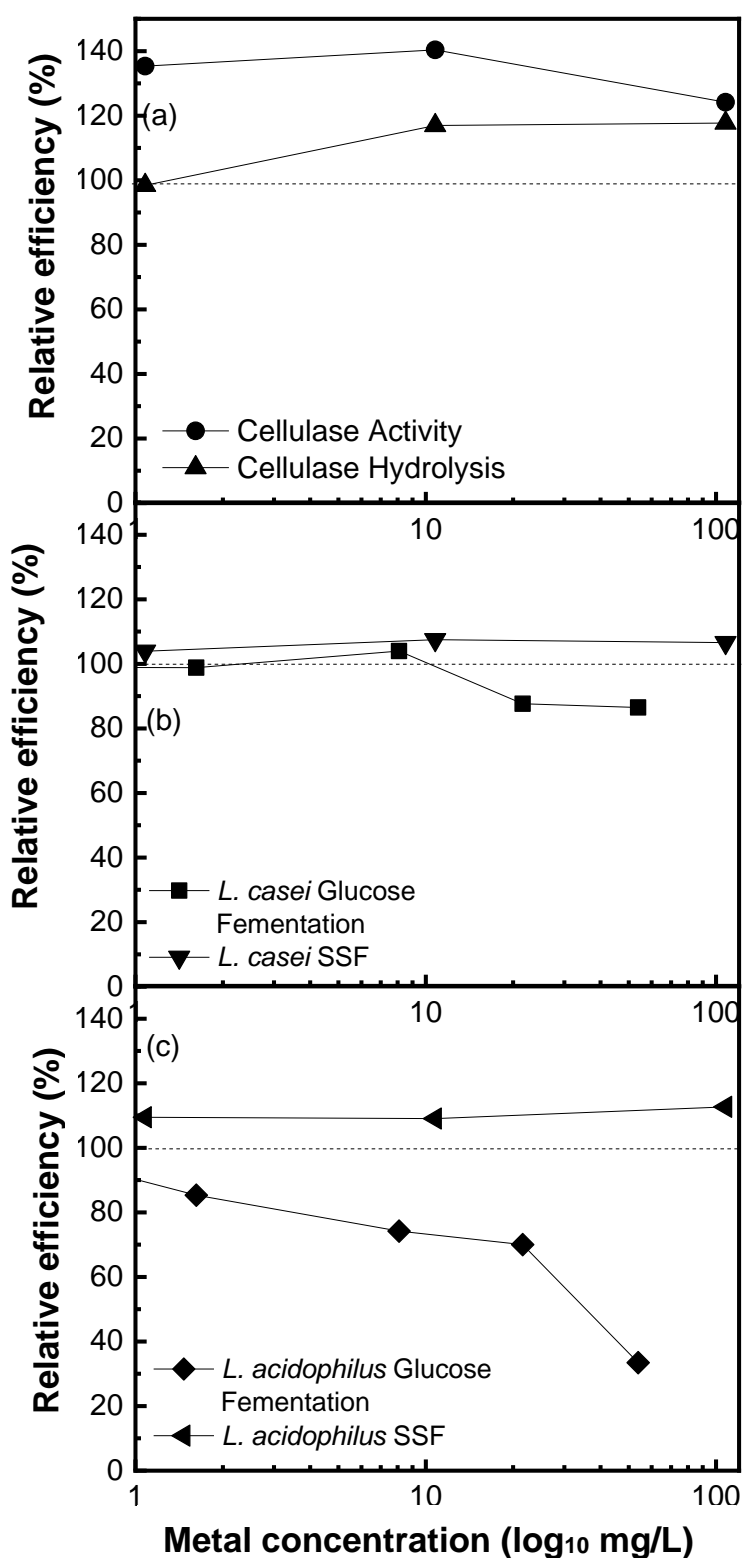

Fig. 3. Impacts of $\mathrm{Cd}^{2+}$ on (a) cellulase activities and enzyme hydrolysis of biomass, (b) glucose fermentation, and (c) SSF of both lactobacilli strains

The bottom panel of Fig. 3c shows the relative efficiencies of lactic acid conversions from glucose and biomass SSF by L. acidophilus. The differences in the impact of the presence of $\mathrm{Cd}^{2+}$ on relative lactic acid conversions from glucose and biomass SSF by L. acidophilus were much larger than those of L. casei. From 8.09 and 21.57 to $53.92 \mathrm{mg} \mathrm{Cu}^{2+} / \mathrm{L}$, the relative efficiencies of lactic acid conversions from glucose by $L$. acidophilus changed from $74.2 \%$ and $70.0 \%$ to $33.4 \%$. The impacts of the presence of $\mathrm{Cd}^{2+}$ on relative lactic acid conversions from glucose by $L$. acidophilus were larger than those of $L$. casei. Differences of the impact of the presence of $\mathrm{Cd}^{2+}$ on relative lactic acid conversions from glucose and biomass SSF were much larger than those of $\mathrm{Cu}^{2+}$ for both Lactobacillus strains. The above findings can assist in finding optimal schemes for biomass conversions under the presence of different metals. 


\section{CONCLUSIONS}

1. According to the dosage concentration for inhibition of lactic acid production, higher tolerance of cellulase to the presence of heavy metals was observed in the order $\mathrm{Cd}^{2+}$ $>\mathrm{Cu}^{2+}>\mathrm{Cr}^{6+}$.

2. The yield of lactic acid was the greatest at a $\mathrm{Cd}^{2+}$ concentration of $107.8 \mathrm{mg} / \mathrm{L}$ and the worst at a $\mathrm{Cr}^{6+}$ concentration of $1414.0 \mathrm{mg} / \mathrm{L}$.

3. Different lactobacilli strains possess a variety of tolerance against each heavy metal. Fundamental data obtained from this study may assist designing optimal utilizing schemes for biomass harvested after phytoremediation.

4. The results of this study validate the viabilities of biochemical conversion processes for fermentable sugars and lactic acid from biomass harvested after phytoremediation, thereby further enhancing the benefits of environmental remediation.

\section{ACKNOWLEDGMENTS}

The financial support from the Taiwan EPA and the Ministry of Science and Technology, Taiwan (MOST 108-2621-M-002-026) are gratefully acknowledged.

\section{REFERENCES CITED}

Abdel-Rahman, M. A., Tashiro, Y., and Sonomoto, K. (2011). "Lactic acid production from lignocellulose-derived sugars using lactic acid bacteria: overview and limits," $J$. Biotechnol. 156(4), 286-301. DOI: 10.1016/j.jbiotec.2011.06.017

Ajala, E. O., Olonade, Y. O., Ajala, M. A., and Akinpelu, G. S. (2020). "Lactic acid production from lignocellulose - A review of major challenges and selected solutions," ChemBioEng Rev. 7(2), 38-49. DOI: 10.1002/cben.201900018

Ameen, F. A., Hamdan, A. M., and El-Naggar, M. Y. (2020). "Assessment of the heavy metal bioremediation efficiency of the novel marine lactic acid bacterium, Lactobacillus plantarum MF042018," Sci. Rep. 10, Article number 314. DOI: 10.1038/s41598-019-57210-3

Aulitto, M., Fusco, S., Nickel, D. B., Bartolucci, S., Contursi, P., and Franzén, C. J. (2019). "Seed culture pre-adaptation of Bacillus coagulans MA-13 improves lactic acid production in simultaneous saccharification and fermentation," Biotechnol. Biofuels 12(1), 1-11. DOI: 10.1186/s13068-019-1382-2.

Chen, H., Chen, B., Su, Z., Wang, K., Wang, B., Wang, Y., Si, Z., Wu, Y., Cai, D., and Qin, P. (2020). "Efficient lactic acid production from cassava bagasse by mixed culture of Bacillus coagulans and Lactobacillus rhamnosus using stepwise $\mathrm{pH}$ controlled simultaneous saccharification and co-fermentation," Ind. Crop. Prod. 146, Article ID 112175. DOI: 10.1016/j.indcrop.2020.112175

CNS 14907 (2005). "Method of test for acid-insoluble lignin in wood," Chinese National Standard, Taiwan, Republic of China.

Cubas-Cano, E., González-Fernández, C., Ballesteros, I., and Tomás-Pejó, E. (2020). "Efficient utilization of hydrolysates from steam-exploded gardening residues for 
lactic acid production by optimization of enzyme addition and $\mathrm{pH}$ control," Waste Manage. 107, 235-243. DOI: 10.1016/j.wasman.2020.04.003

Djukić-Vuković, A., Mladenović, D., Ivanović, J., Pejin, J., and Mojović, L. (2019). "Towards sustainability of lactic acid and poly-lactic acid polymers production," Renew. Sust. Energ. Rev. 108, 238-252. DOI: 10.1016/j.rser.2019.03.050

Geiger, E. M., Sarkar, D., and Datta, R. (2019). "Evaluation of copper-contaminated marginal land for the cultivation of vetiver grass (Chrysopogon zizanioides) as a lignocellulosic feedstock and its impact on downstream bioethanol production," Appl. Sci. 9(13), Article number 2685. DOI: 10.3390/app9132685

Hammes, W. P., and Hertel, C. (2006). "The Genera Lactobacillus and Carnobacterium," in: The Prokaryotes, S. Falkow, E. Rosenberg, K. H. Schleifer, E. Stackebrandt, M. Dworkin (eds.), Springer Science+Business Media, LLC, New York, NY, USA, pp. 320-403.

Karaca, A., Cetin, S. C., Turgay, O. C., and Kizilkaya, R. (2010). "Effects of heavy metals on soil enzyme activities," In Soil heavy metals (pp. 237-262). Springer, Berlin, Heidelberg.

Ko, C. H., Yang, B. Y., Lin, L. D., Chang, F. C., and Chen, W. H. (2020). "Impact of pretreatment methods on production of bioethanol and nanocrystalline cellulose," $J$. Clean. Prod. 254, Article ID 119914. DOI: 10.1016/j.jclepro.2019.119914

Ko, C. H., Yu, F. C., Chang, F. C., Yang, B. Y., Chen, W. H., Hwang, W. S., and Tu, T. C. (2017). "Bioethanol production from recovered napier grass with heavy metals," $J$. Environ. Manage. 203(Part 3), 1005-1010. DOI: 10.1016/j.jenvman.2017.04.049

Komesu, A., de Oliveira, J. A. R., da Silva Martins, L. H., Maciel, M. R. W., and Maciel Filho, R. (2017). "Lactic acid production to purification: A review," BioResources 12(2), 4364-4383. DOI: 10.15376/biores.12.2.komesu

Kumar, V., Yadav, S. K., Kumar, J., and Ahluwalia, V. (2020). "A critical review on current strategies and trends employed for removal of inhibitors and toxic materials generated during biomass pretreatment," Bioresource Technol. 299, Article ID 122633. DOI: 10.1016/j.biortech.2019.122633

Le Guenic, S., Chaveriat, L., Lequart, V., Joly, N., and Martin, P. (2019). "Renewable surfactants for biochemical applications and nanotechnology," J. Surfactants Deterg. 22(1), 5-21. DOI: 10.1002/jsde. 12216

Rawoof, S. A. A., Kumar, P. S., Vo, D. V. N., Devaraj, K., Mani, Y., Devaraj, T., and Subramanian, S. (2020). "Production of optically pure lactic acid by microbial fermentation: A review," Environ. Chem. Lett., 1-18. DOI: 10.1007/s10311-02001083-w

TAPPI T204 cm-07 (2007). "Solvent extractive of wood and pulp," TAPPI Press, Atlanta, GA, USA.

TAPPI T211 om-02 (2002). "Ash in wood, pulp, paper and paperboard: Combustion at $525^{\circ} \mathrm{C}$, , TAPPI Press, Atlanta, GA, USA.

TAPPI T223 cm-01 (2001). "Pentosans in wood and pulp," TAPPI Press, Atlanta, GA, USA.

TAPPI T249 cm-09 (2009). "Carbohydrate composition of extractive-free wood and wood pulp by gas-liquid chromatography," TAPPI Press, Atlanta, GA, USA.

TAPPI T258 om-06 (2006). "Basic density and moisture content of pulpwood," TAPPI Press, Atlanta, GA, USA.

Tu, W. L., Hsu, T. C., Wang, C. A., Guo, G. L., and Chao, Y. (2019). "Using novel Lactobacillus plantarum to produce lactic acid from lignocellulosic biomass in an 
integrated simultaneous saccharification and fermentation process," BioResources 14(2), 3873-3885. DOI: 10.15376/biores.14.2.3873-3885

Unrean, P. (2018). "Optimized feeding schemes of simultaneous saccharification and fermentation process for high lactic acid titer from sugarcane bagasse," Ind. Crop. Prod. 111, 660-666. DOI: 10.1016/j.indcrop.2017.11.043

Wang, B. S. P., and Chien, C. T. (2016). Seeds of the economically important trees in Taiwan (Report No. 268), Taiwan Forestry Research Institute, Taipei, Taiwan.

Wu, Y., Wang, M., Yu, L., Tang, S. W., Xia, T., Kang, H., Xu, C., Gao, H., Madadi, M., Alam, A., et al. (2020). "A mechanism for efficient cadmium phytoremediation and high bioethanol production by combined mild chemical pretreatments with desirable rapeseed stalks," Sci. Total Environ. 708, Article ID 135096. DOI: 10.1016/j.scitotenv.2019.135096

Yu, H., Zou, W., Chen, J., Chen, H., Yu, Z., Huang, J., Tang, H., Wei, X., and Gao, B. (2019). "Biochar amendment improves crop production in problem soils: A review," J. Environ. Manage. 232, 8-21. DOI: 10.1016/j.jenvman.2018.10.117

Article submitted: September 4, 2020; Peer review completed: October 25, 2020; Revised version received and accepted: November 22, 2020; Published: December 11, 2020.

DOI: $10.15376 /$ biores.16.1.882-892 